\title{
Introduktion til dette nummer af Journalistica
}

\section{AF CHARLOTTE WIEN}

Temaet „Forskning og Journalistik“ er et meget bredt tema for et forskningstidskrift, der behandler forskning i journalistik og medier. Derfor repræsenterer artiklerne i dette nummer også en bred vifte af forskellige metodiske og teoretiske tilgange til studiet af journalistikken.

Temaet er valgt fordi det ofte hævdes, at både journalistikken og forskningen bevæger sig i flere forskellige retninger i disse år: På den ene side tvinger markeds- og ansættelsesvilkår journalisterne væk fra fordybelse og til at levere tekster til en stadigt mere og mere indholdsløs form. På den anden side efterspørger et andet publikum en type journalistik, hvor der stilles stadig større krav om faglig fordybelse og metodisk transparens. Tilsvarende mødes forskerne på den ene side af et stigende krav om publikationer i internationale fagfællebedømte tidsskrifter og på den anden side af et krav om formidling af forskningsresultater til den brede befolkning.

Noget af dette bringer i disse år dele af forskningen og dele af journalistikken tættere på hinanden, mens andre dele tvinges længere og længere væk fra hinanden. Journalistica søger at bygge bro og samle trådene ved på den ene side at være et internationalt orienteret fagfællebedømt tidsskrift med en høj faglig standard, mens vi på den anden side ønsker at sikre, at de artikler, der bringes heri er let tilgængelige og velformidlede. Håbet med dette nummer af Journalistica er således, at både forskere og journalister vil kunne finde inspiration til deres arbejde heri.

Man kan mene, at temaet er for bredt, fordi afstanden mellem journalistik og forskning er for stor og fordi den faglige og emnemæssige spredning af artiklerne i dette nummer ligeledes er for 
6 // JOURnalistica - NR. $2 \cdot 2010$

stor. Det mener vi ikke. Tvært i mod: For netop ved at præsentere en bred vifte af teorier og tilgange illustrerer dette nummer af Journalistica, hvor mangfoldig forskningen i Journalistik er. 